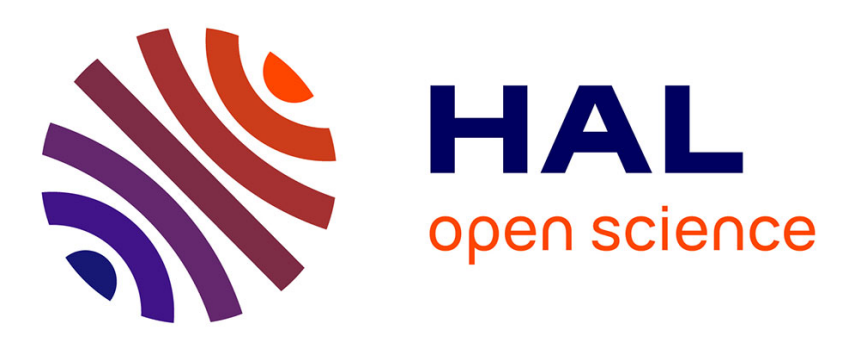

\title{
The Northern Iranian Central Plateau at the End of the Pleistocene and Early Holocene: The Emergence of Domestication
}

\author{
Hamed Vahdati Nasab, Sanaz Shirvani, Solange Rigaud
}

\section{- To cite this version:}

Hamed Vahdati Nasab, Sanaz Shirvani, Solange Rigaud. The Northern Iranian Central Plateau at the End of the Pleistocene and Early Holocene: The Emergence of Domestication. Journal of World Prehistory, 2019, 32 (3), pp.287-310. 10.1007/s10963-019-09133-0 . hal-03001757

\section{HAL Id: hal-03001757 \\ https://hal.science/hal-03001757}

Submitted on 12 Oct 2021

HAL is a multi-disciplinary open access archive for the deposit and dissemination of scientific research documents, whether they are published or not. The documents may come from teaching and research institutions in France or abroad, or from public or private research centers.
L'archive ouverte pluridisciplinaire HAL, est destinée au dépôt et à la diffusion de documents scientifiques de niveau recherche, publiés ou non, émanant des établissements d'enseignement et de recherche français ou étrangers, des laboratoires publics ou privés. 


\title{
The Northern Iranian Central Plateau at the End of the Pleistocene and Early Holocene: The Emergence of Domestication
}

\author{
Hamed Vahdati Nasab ${ }^{1}$ Sanaz Shirvani ${ }^{2} \cdot$ Solange Rigaud ${ }^{3}$
}

\begin{abstract}
Until recently, the Iranian Central Plateau (ICP) was considered to have been unoccupied at the end of the Pleistocene (Marshall 2012 in 'Missing Links: Demic Diffusion and the Development of Agriculture on the Central Iranian Plateau'. Durham University e-Theses. http://ethes es.dur.ac.uk/3547/), raising questions about the mechanisms that drove Neolithic diffusion in this area. However, recent field data has provided new insights into the rise of domestication here. Reassessment of the local chronology during the Early Holocene reveals consistent occupation of the ICP throughout the Epipaleolithic/Mesolithic. Plant and animal remains indicate that Mesolithic communities preserved a purely foraging lifestyle, yet data for the Early Neolithic shows that communities produced fully domesticated resources. This clear economic rupture suggests the introduction of farming technologies from other regions. Additionally, the central geographic position of the ICP between the Zagros and western Central Asia, and the correspondence in material culture between the eastern sites of the ICP and the Zagros suggest that the region was a hot spot of connections favourable to the eastward diffusion of the Neolithic.
\end{abstract}

Keywords Iranian Central Plateau · Domestication · Southeastern Caspian Sea · Mesolithic $\cdot$ Neolithic

\section{Résumé}

Jusqu'à récemment, les mécanismes de diffusion du mode de vie néolithique sur le Plateau Central Iranien (PCI) ont été largement débattus et la région était considérée inoccupée à la fin du Pléistocène (Marshall, 2012). De nouvelles données de terrain

\footnotetext{
$\triangle \quad$ Hamed Vahdati Nasab

vahdati@modares.ac.ir

1 Department of Archeology, Tarbiat Modares University, Tehran, Iran

2 Department of Archeology, University of Tehran, Tehran, Iran

3 UMR 5199 - PACEA, CNRS, Université de Bordeaux, Bâtiment, B8, Allée Geoffroy Saint Hilaire, 33615 Pessac, France
} 
offrent d'autres perspectives quant à l'adoption de la domestication sur le PCI. La révision de la chronologie régionale du début de l'Holocène montre une occupation durable du plateau au cours de l'Epipaléolithique et du Mésolithique. Les vestiges de faunes et de plantes montrent que les communautés mésolithiques ont préservé une économie reposant exclusivement sur la chasse et la cueillette. En revanche, les données sur le début du Néolithique indiquent que les sociétés exploitaient des ressources pleinement domestiquées. Cette rupture économique claire suggère l'introduction des technologies agricoles en provenance d'autres régions. De plus, la position centrale du PCI entre le Zagros et l'Ouest de l'Asie Centrale et les correspondances dans la culture matérielle entre les sites localisés à l'est du PCI et le Zagros suggère que la région était une zone clef pour établir et maintenir des réseaux de contacts favorables à la diffusion du Néolithique vers l'Est.

Mots clefs Plateau Central Iranien · Domestication - Mer Caspienne · Mésolithique - Néolithique

\section{The First Domestications in the Near East and their Implications for the Iranian Central Plateau}

The transition to farming corresponds to the process by which human groups switched from hunting and gathering wild resources to food production based on crop cultivation and stockbreeding. This transformation occurred independently, at different times and in various regions of the world (Barker 2009); it is thought to result from various causes, including climate change (Rowley-Conwy and Layton 2011; Weninger et al. 2006); human-plant co-evolution (Rindos 1984); demography (Bocquet-Appel 2002; Bowles 2011); social competition and inequality (Wright 2014); or a combination of these (Ammerman and Biagi 2003; Bocquet-Appel 2008). However, to what extent these different mechanisms played a role in the emergence and diffusion of food production is still highly debated.

Archaeological evidence from the Levant shows that the transition to farming is rooted in more than 10,000 years of gradual technological and cultural innovations, which led communities to switch from a foraging economy to sedentism and food production (Maher et al. 2012). Cultivation was first initiated by hunter-gatherers (Fuller et al. 2012, 2014a) 14,500 to 11,500 years ago (Riehl et al. 2012), but the first evidence of food resource management can be traced back to the Upper Paleolithic, when foraging communities diversified their diet and turned to a delayed-return economy in order to cope with food shortages and environmental constraints (Stiner 2001). The emergence of food production, therefore, appears to be entrenched in a combination of cultural, social and economic changes, including new skills related to targeted and selective hunting, the optimal use of local diversified resources, and technological innovations for storage (Diamond 1999, pp. 110-112).

Climatic changes (the Younger Dryas, in particular) have been interpreted as the major reason for the adoption of agriculture and herding during the Early Holocene (Bar-Yosef and Valla 1990; Bar-Yosef and Belfer-Cohen 1989). However, several previous climatic fluctuations during the Paleolithic (Brown et al. 2009) do not appear 
to have led to major economic changes such as food production. It is more likely, therefore, that specific technological innovations, changes in perception of the surrounding plants and animals, and improvement in the human skills involved in managing the long-term availability of resources (Diamond 1999:, pp. 110-112) led to successful food production.

The emergence of domestication occurred in regions where the wild ancestor of the first domesticated plant and animal species was already present in the local environment (Binford 1968, p. 328; Flannery 1969, p. 74; Zeder 2008, 2012). In the Near East, archaeobotanical and zooarchaeological data show that initial domestication of the four major species, including wheat, barley, goats, and sheep, goes back at least 11,500 years (if not earlier), and emerged independently in different parts of the Fertile Crescent (Zeder 2011; Fuller et al. 2012). From there, farming technologies and domesticated plant and animal species diffused westward across Europe (Zeder 2008, 2011) and eastward through the northern Zagros (Naderi et al. 2007).

Studies on the Fertile Crescent have revealed a combination of cultural diffusion, along with some degree of demic diffusion between farmers and herders in these areas (Brown et al. 2012). We can therefore expect that similar diversified cultural and population events occurred in the eastern regions; however, due to the lack of adequate archaeobotanical and zooarchaeological data, the spread of domestication towards the east is not as well documented as in the west.

The core of this article concerns the Iranian Central Plateau (ICP), where the development of food production has scarcely been investigated, in contrast to the Taurus and Zagros regions. Indeed, until recently, this lack of field data led to the hypothesis that the region was unoccupied at the end of the Pleistocene (Marshall 2012), implying that the farming transition in the ICP resulted from the diffusion and adaptation of domesticated plants and mammals originally exploited in the Zagros and Taurus regions. However, recent and challenging data has provided new insights on the consistent occupation of the ICP throughout the Epipaleolithic and Mesolithic. This paper, therefore, is an opportunity to review all the available data in order to discuss the different cultural and demic processes that may have been at work during the transition to farming in this region.

\section{The Geomorphology of the Iranian Central Plateau}

The complex geomorphology of the Iranian Central Plateau (ICP) corresponds to diversified environments more or less suitable for supporting both foraging activities and a sedentary/agricultural lifestyle. The ICP is bounded by the Zagros Mountains to the west, the Alborz Mountains to the north and northeast, and the Lut Desert to the south (Fig. 1). The western plateau is elevated and culminates at an altitude of 900-1500 m above sea level (Fisher 1968, p. 14). The Central Desert (Dashte Kavir) is located at the centre of the ICP, and corresponds to the remains of a large lake that once covered the region (Krinsley 1970). Between these two large and contrasting geomorphological environments (desert versus high altitude mountains) of the northern ICP, only a few restricted 'corridors' were suitable for human 


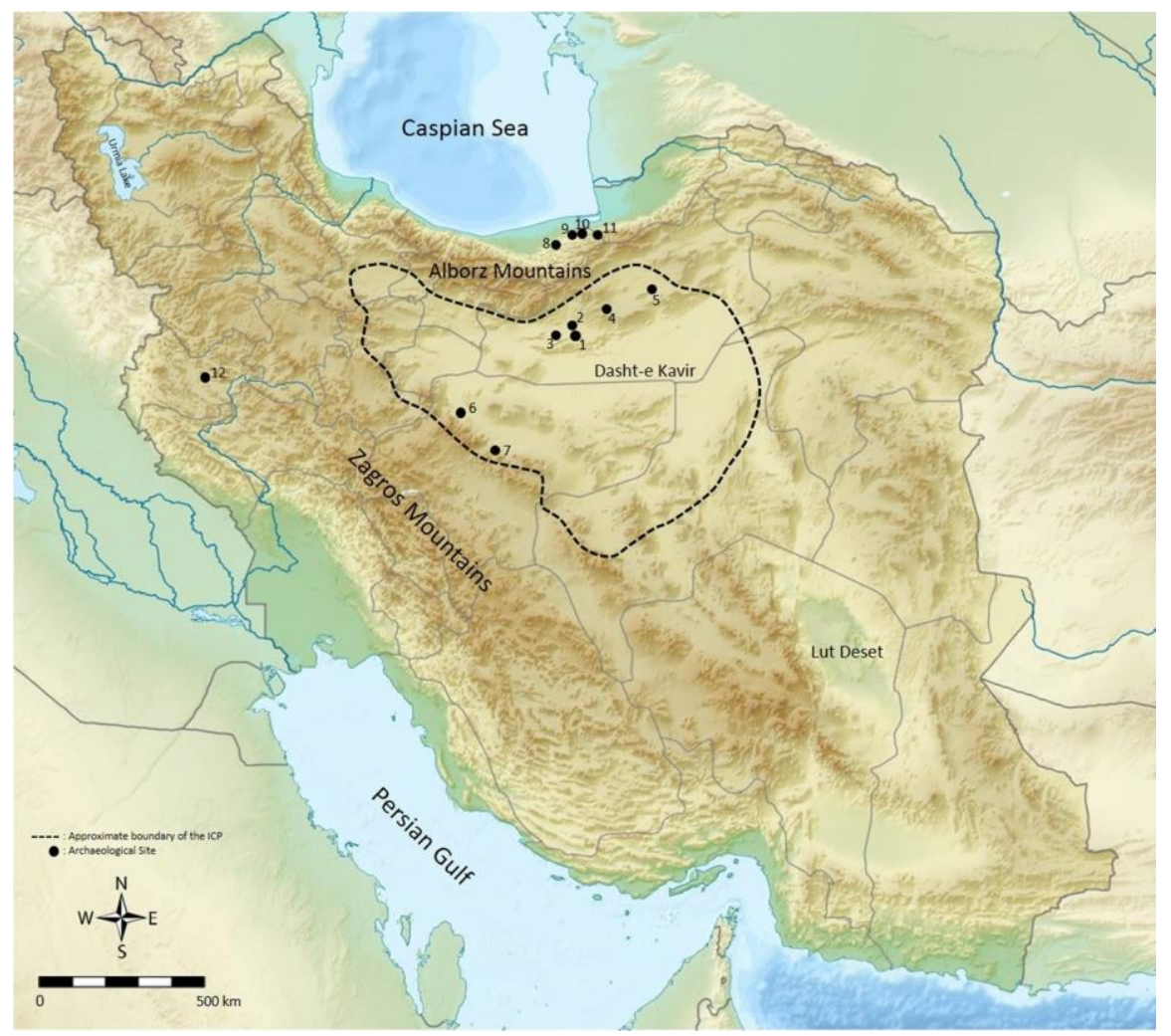

Fig. 1 Location of some of the sites mentioned in the Iranian Plateau. (1) Mirak, (2) Delazian, (3) SoofiAbad, (4) Chah-e Jam, (5) Chakhmaq, (6) Sefid-Ab, (7) Bardia, (8) Komishan, (9) Huto, (10) Kamarband, (11) Ali Tepe, (12) Sarab

settlement and population movement (Vahdati Nasab and Clark 2014; Vahdati Nasab et al. 2013). The extent of these corridors varied at different times due to climatic oscillations which regularly constrained or enhanced the expansion of the Central Desert (Kehl, 2009). This article mainly focuses on the northern edge of the ICP, corresponding to the region located between the Alborz Mountains and the Central Desert (Fig. 1), where a rich Paleolithic record has been documented (Conard and Ghasidian 2011; Conard et al. 2007, 2009; Heydari Guran and Ghasidian 2011; Vahdati Nasab and Clark 2014; Vahdati Nasab and Hashemi 2016; Vahdati Nasab et al. 2013). From the downstream Alborz Mountains towards the upstream desert area, several geomorphological variations have been identified, including stony/ rocky highlands, alluvial fans or rocky/gravel slopes, piedmont plains, desert areas, and salt flats in the middle of the desert.

The Alborz Mountains are geomorphologically very different from the Zagros Mountains due to their different orogenic system (Oberlander 1968, p. 200). Alluvial fans, corresponding to debris flow generated from the mountains' degradation, are composed of hollow-textured coarse-grained sediments the size of gravel and sandstone grains and include low clay and silt content. Due to their porous properties, 
the Alborz alluvial fans favour surface water storage, inauspicious for agriculture. Next to the alluvial fans, the Garmsār, Semnan, Dāmghan, and Šāhrud piedmont plains (Roustaei 2012, 2016) represent the major and most suitable areas for human settlement in this region (Vahdati Nasab and Clark 2014). The plains end in desert areas with alkaline soil, considered unsuitable for agriculture (Vahdati Nasab and Hashemi 2016). Finally, the outlets of several seasonal streams flowing from the northern highlands form extensive salt flats areas (in particular, Masileh and Howz-e Soltan salt lakes near Qom, and the Chah-e Jam Desert in Dāmghan) located in the lowest part of the desert area, which were once the ICP lakes.

\section{The Iranian Central Plateau Newcomers}

When and how the first modern human populations (Homo sapiens sapiens) entered the ICP is still debated (Groucutt et al. 2015), with two regions being alternatively proposed for the origins of the Aurignacian culture: the Zagros Mountains (Olszewski and Dibble 1994; Rose 2010) and the eastern areas of the northeastern ICP in Afghanistan (Otte et al. 2007). The presence of earlier Aurignacian occupations in largely documented regions such as the Levant (Ksar Akil in Lebanon) (Shea 2013, p. 117), Turkey (Üçağizli), and Syria (Umme el Tlel); the unsettled Upper Paleolithic chronology of the Zagros and of the northern ICP, and the scarcity of the Aurignacian archaeological remains in these areas, make the Zagros Mountains/ northeast ICP origin hypotheses very controversial.

Due to the lack of direct paleoclimatic data from the ICP, only data available for surrounding regions in the northeast (the Mashhad and Kalate Naderi regions: Karimi et al. 2011; Vlaminck et al. 2018), north (Caspian Sea: Yanina 2012), and west (Urmia and Neor lakes: Stevens et al. 2012; Azizi et al. 2013) can be used to simulate climatic conditions in the ICP (Fig. 2). At the beginning of the Upper Paleolithic, c. 40-32 ka cal BP, the ICP had a relatively warm and humid climate. A relative temperature drop, c. 32-24 ka cal BP, is related to the Caspian Sea's regression to 50-58 m lower than its current level (Coolidge 2005, p. 4). This phenomenon, called the Early Khvalynian Glaciation (Mamedov 1997) was similar to the Bryansk Interval in Europe (Harris 2010, p. 21). Paleoclimatic data from Lake Urmia confirms that the region had a relatively cold and dry climate during this period (Djamali et al. 2008). The Last Glacial Maximum (LGM) began around 24-23 ka cal BP and continued until 20-19 ka BP (Harris 2010, p. 21). The maximum temperature in the severely cold climate of the ICP reached $10-12{ }^{\circ} \mathrm{C}$ in June/July, which led to large scale regional vegetation degradation because of severe soil erosion at the northern edge of the ICP, and significant biomass transformations throughout the region (Djamali et al. 2008). Moreover, this very low temperature increased lake and river aridity - a process with visible impacts that can still be observed today (Karimi et al. 2011).

The distribution of human occupations in the ICP during the Upper Paleolithic indicates an obvious decrease in settlements (Vahdati Nasab and Clark 2014). 


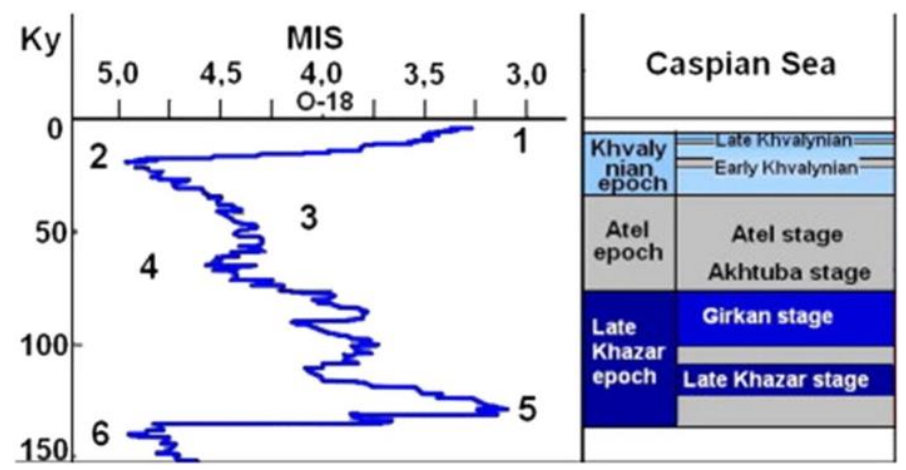

Fig. 2 Paleoclimate of the Caspian Sea during the end of Pleistocene, after Yanina et al. (2012), with some modifications

Besides the loss of environmental resources, severe climatic changes resulted in major desertification in the northern part of the Iranian Plateau (e.g. the Central Desert and Karakum Desert). However, cultural innovations may have contributed in helping ICP modern humans overcome these fluctuant climatic conditions and repeated arid episodes; for example, in the production of throwing-spears, such as Arjeneh points (Fig. 3), which allowed selective ungulate hunting (e.g. gazelle) in the treeless plains during the cold and dry periods (Olszewski and Dibble 1994). Despite efficient technological adaptations that may have helped humans cope with this changing environment, a clearly uneven distribution of archaeological sites is still observed in the Upper Paleolithic of the northeast of Iran (Davis 1990; Davis and Ranov 1999; Derevianko 2010). The only Upper Paleolithic sites discovered in the ICP are Mirak (Fig. 4a), Delazian (Fig. 4b), Chah-e Jam (Fig. 4c), and SoofiAbad on the northern edge of the Central Desert (Vahdati Nasab et al. 2019; Vahdati Nasab and Clark 2014; Vahdati Nasab and Hashemi 2016), and Bardia and Sefid Ab in the east of the Central Desert (Conard and Ghasidian 2011; Conard et al. 2007, 2009; Heydari Guran and Ghasidian 2011; Shidrang 2009). These settlements can probably be traced back to the beginning or the end of the Upper Paleolithic (40-32 ka and 20$15 \mathrm{ka}$ cal BP), when moderate climatic conditions in these regions enabled the creation of short-term settlements. However, in the absence of an absolute chronology for these occupations, their chrono-cultural attribution has to be viewed with caution. The recent excavation of the Paleolithic site of Mirak, located in the ICP, tends to secure this hypothesis by revealing the existence of Upper Paleolithic layers (Vahdati Nasab et al. 2019).

\section{The Epipaleolithic/Mesolithic of the ICP}

The LGM period not only reduced, or dried out, the ICP's lakes, it also reactivated perennial and seasonal water resources, extended vegetation cover, and subsequently resulted in major faunal variations in the region (Karimi et al. 2011). Evidence derived from Caspian Sea level fluctuations indicate that several short-term cold 

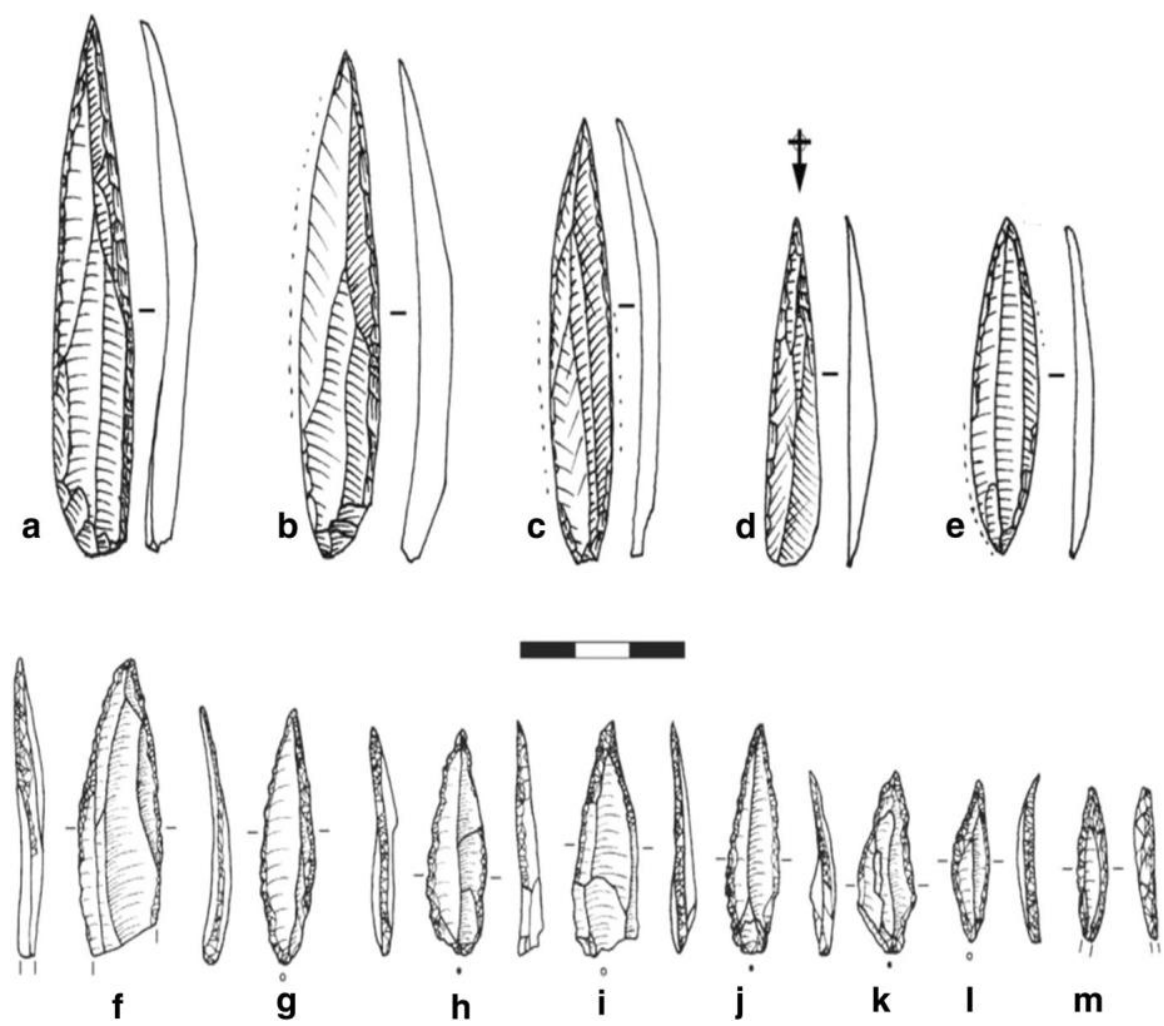

Fig. 3 Examples of Arjeneh points from the Upper Paleolithic sites of Yafteh (a-e, after Bordes and Shidrang 2009) and Boof [f--m, after Conard and Ghasidian (2011)] in Iran. Arjeneh points, also known as Font-Yves or el-Wad points, are made on bladelets with bilateral retouches

climate oscillations occurred in the ICP from $20 \mathrm{ka}$ to $11.5 \mathrm{ka}$ cal BP (Clauer et al. 2000; Harris 2010, p. 21; Ollivier et al. 2015). The first cold period, called the Eltonian regression in Soviet literature, lasted for 500 years from $17.5 \mathrm{ka}$ to $17 \mathrm{ka}$ cal BP (Harris 2010, p. 21); it was followed by a warming phase until $12.7 \mathrm{ka}$ cal BP, and then the cold Younger Dryas, which lasted for 900 years (Birks et al. 2015).

In contrast to the northern slopes of the Alborz and Zagros Mountains, the Epipaleolithic/Mesolithic settlements from the southern slopes of Alborz were surveyed but not properly excavated using modern field methods; the northern ICP is even less well documented. This chronological gap, between the Late Paleolithic and the Early Neolithic, has encouraged some researchers to look for the origin of the first ICP Neolithic communities outside Iran's borders (Marshall 2012, p. 436). The successful adaptation of Epipaleolithic communities to their environment (even in the cold and dry periods) in other regions suggests their continuous presence in the area. In addition, evidence of Epipaleolithic/Mesolithic occupations have been found at many Upper Paleolithic sites in other parts of the ICP, including Delazian, Chah-e Jam, and Soofi-Abad on the northern edge of the Central Desert (Vahdati Nasab and 


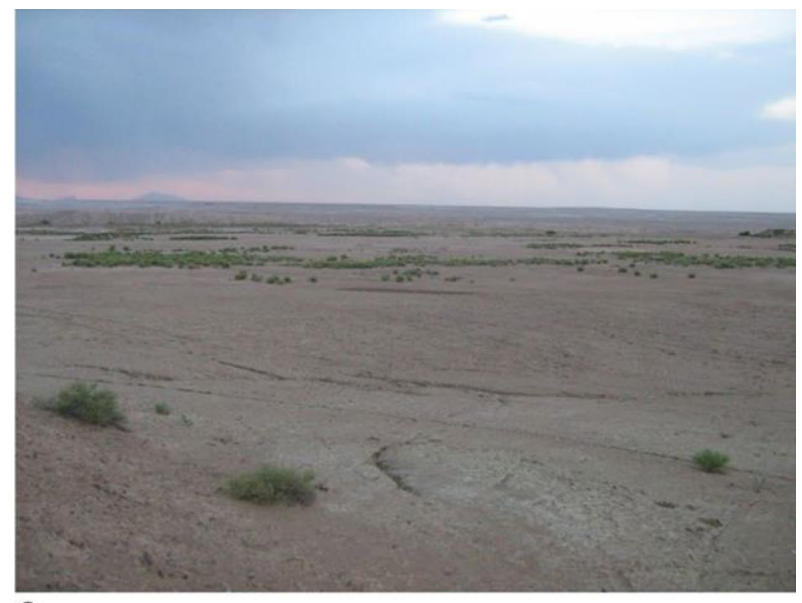

a

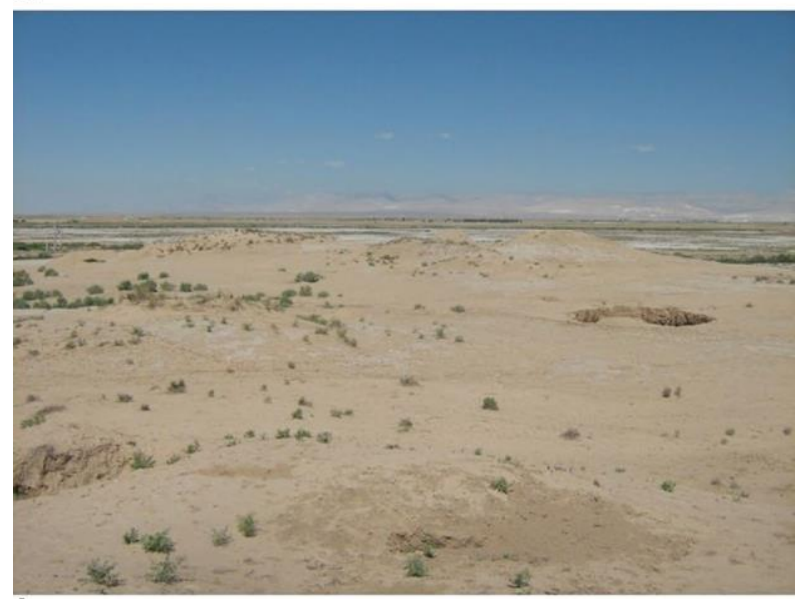

b

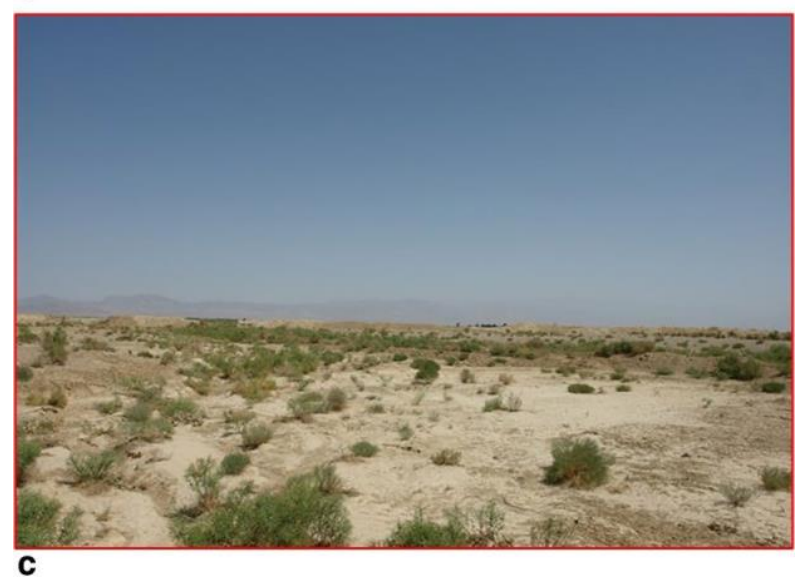

Fig. 4 Landscape view of the ICP Upper Paleolithic sites. a Mirak, b Delazian, $\mathbf{c}$ Chah-e Jam Clark 2014; Vahdati Nasab and Hashemi 2016); and Bardia (Conard et al. 2009) and Sefid Ab (Shidrang 2009) on the western edge of the Central Desert. This is in 
complete agreement with the data from Zagros, where many archaeological occupations attributed to the Epipaleolithic/Mesolithic have been identified (e.g. Olszewski, 2013). In this area in particular, changes in tool kit composition are visible through the frequent use of grinding stones relating to plant processing. This technological innovation was developed in correspondence with a new economy based on cultivation and livestock management and the adoption of a semi-sedentary lifestyle (Maher et al. 2012). A similar grinding technology and reduced mobility have, however, not yet been identified in the ICP.

\section{Archaeological Evidence of Early Domestications in the ICP}

\section{Northern Alborz Mountains and Southeastern Caspian Sea}

Evidence from Epipaleolithic/Mesolithic and Neolithic settlements in the southeastern Caspian Sea was obtained from the excavations of the Ali Tepe, Huto, Kamarband (Belt), and Komishan caves. Ali Tepe was excavated by Charles McBurney, who discovered 23 Mesolithic layers (McBurney 1968, Fig. 5). Here, an important climatic record was obtained which showed human adaptation to diversified food resources during a period of frequent climatic changes (Mellaart 1975 , p. 208). Based on the relative frequency of mammalian and mollusk remains, McBurney divided the Ali Tepe stratigraphic sequence into five main occupations attributed to the northern European Late Glacial/Early Postglacial period. Radiocarbon dates point to a period of occupation between 13,000 and 11,800 cal BP (Harris 2010, p. 55). The faunal spectrum indicates major changes in prey selection at the end of the Epipaleolithic (end of stage IVb identified at the site), characterized by 'a sudden increase in wild goat/sheep and jackal/fox remains, followed by their gradual reduction at the end of the occupation, which coincided with an increase of gazelle remains (30\%), onager, wild pig, aurochs, and deer' (McBurney 1968, p. 397). Results obtained at Ali Tepe show no evidence of domestic animals in the region during this period, indicating that communities kept their hunter-gatherer lifestyle until the end of the Epipaleolithic/Mesolithic.

The Kamarband (Belt) and Huto caves were excavated in the late 1940s and early 1950s by C. S. Coon (Figs. 6, 7). During the excavation, 28 stratigraphic layers were identified in Kamarband (Coon 1951). Coon suggested approximate dates for the earliest Mesolithic occupation layer 11,500 years ago (c. 13,400 cal BP), and the beginning of the Neolithic c. 8500 years ago (c. 9500 cal BP). The pre-pottery Neolithic (PPN) at the Kamarband cave was recently dated to 8140-7910 cal BP (Gregg and Thornton 2012) and the pottery Neolithic to 7650 cal BP (Gregg and Thornton 2012). The presence of domesticated species of caprids is evidenced for the first time in the PPN layers of Kamarband cave. This statement relies on the sheep and goat mortality profile from layer 7 and above, characterized by the overrepresentation of immature animals, suggesting complex herd management related to domestication (Coon 1951, p. 47). The faunal material was reassessed decades later and 


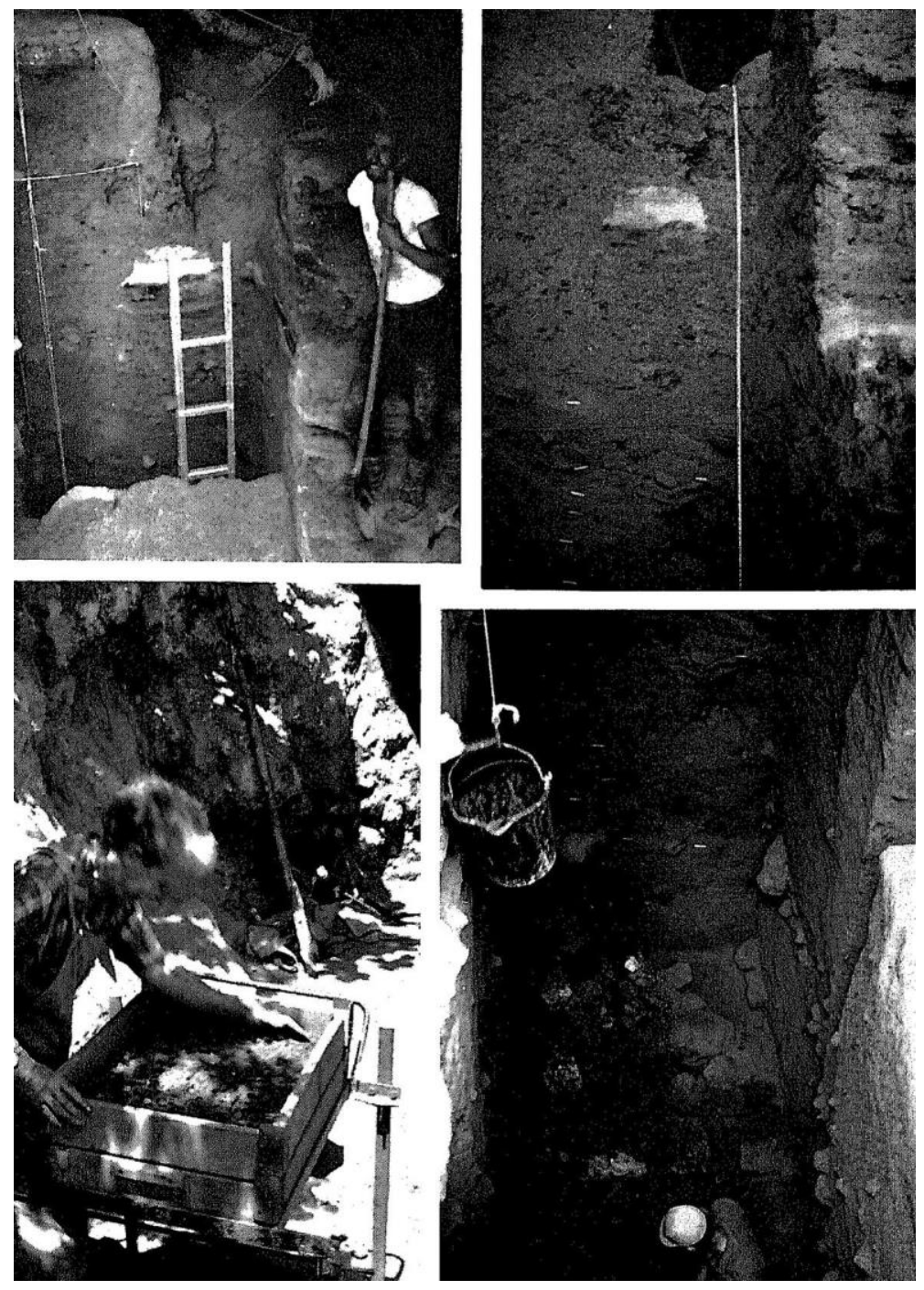

Fig. 5 Ali Tepe during the excavation, from McBurney (1968)

evidence of domestication at the site was strengthened by the faunal spectrum showing ' $12 \%$ to $84 \%$ of ovicaprid, while gazelle drops from $62 \%$ to $8 \%$, and aurochs from 22\% to 0\%' (McBurney 1968, p. 408).

Coon (1952) reported 17 cultural layers in the Huto cave, which included Mesolithic and Neolithic remains. The Mesolithic occupation was dated to approximately $11,000-8000 \mathrm{ka}$ cal BP (c. 12,800-8900 cal BP), followed by the Early Neolithic and pottery Neolithic periods (Harris 2010, p. 57; Gregg and Thornton 2012). The faunal data shows that domesticated ovicaprids were present in all the Neolithic layers (Coon 1952). 


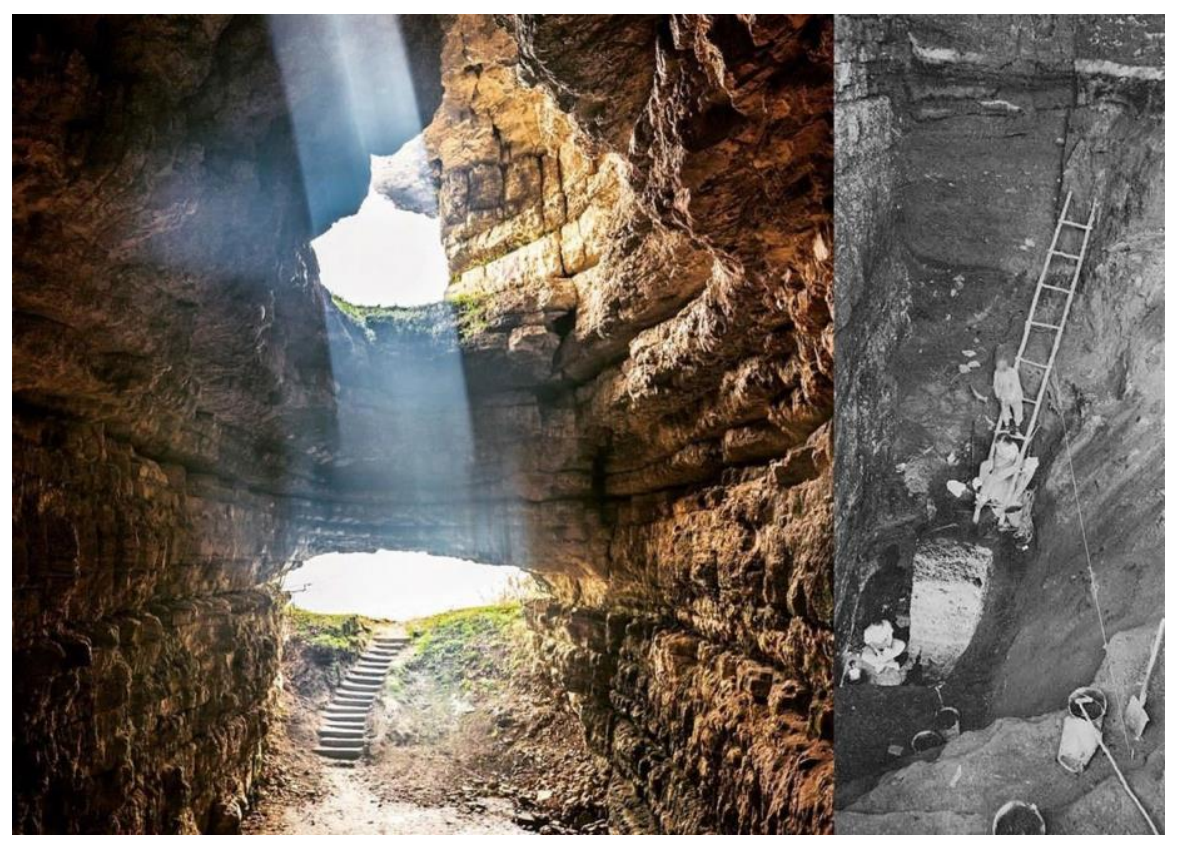

Fig. 6 Present day Huto and photo during the excavation, after Coon (1952)

More recent information on the Mesolithic/Neolithic culture was obtained from the southeastern Caspian Sea with the excavation of the Komishan cave (Vahdati Nasab et al. 2011; Jayez and Vahdati Nasab 2016). The excavation evidenced that recent industrial activity had deeply disrupted the Neolithic and Mesolithic-Neolithic transitional layers, leaving only the Mesolithic layers intact (Fig. 8), dating to 11,77110,682 cal BP (Vahdati Nasab et al. 2011). Analysis of the faunal remains indicated the intense exploitation of gazelles, birds, and marine resources (Knapp 2012; Mashkour 2004; Mashkour et al. 2010). Gazelle, most likely goitered gazelle (Gazelle subgutturosa), was the most commonly exploited herbivore in Komishan. Other mammal remains were less frequent but included Aurochs (Bos primigenius), Persian fallow deer (Dama mesopotamica), red deer (Cervus elaphus), wild sheep (Ovis orientalis), wolf (Canis lupus), Cape hare (Lepus capensis), and European hedgehog (Erinaceus europeus) (Knapp, 2012). These findings suggest that huntergatherers lived in the Caspian Sea region and had access to a rich diet based on wild resources.

Modern field methods were not used during the excavation of the Huto, Kamarband, or Ali Tepe caves, and the floatation technique was not common for gathering carpological remains; therefore, the only plant remains in the southeastern Caspian Sea region have been reported from the Komishan cave (2009 excavations). In the case of cereals, a few barley grains (Hordeum vulgare) were identified in disturbed layers but no barley chaff remains were found in the samples. A number of legume seed remains were identified, such as lentils, which morphometry identified as coming from the wild species Lens orientalis. In addition, some small legume 


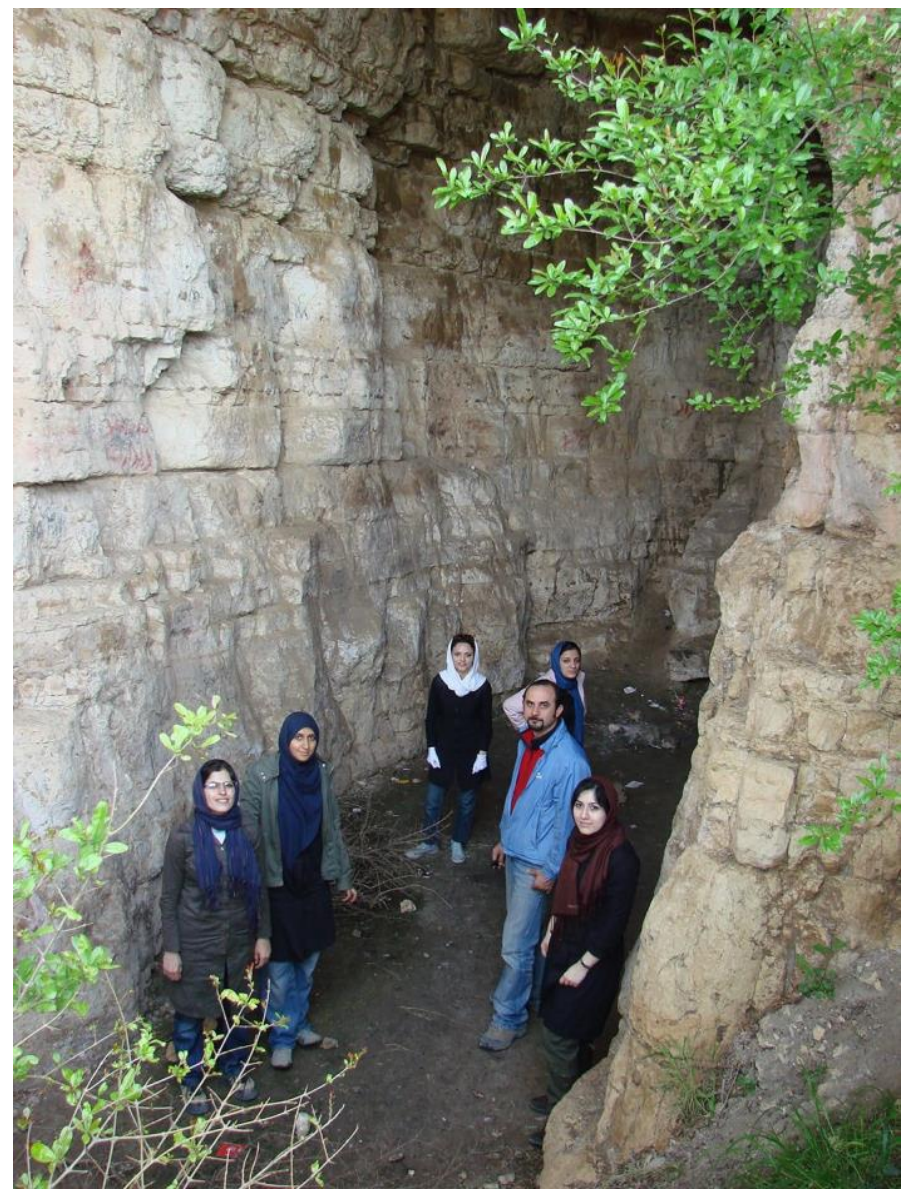

Fig. 7 Present day Kamarband (personal archive of H. Vahdati Nasab)

crops were identified as Vicia ervilia (bitter vetch). Seeds from the two fruit species Mespilus germanica and Elaeagnus angustifolia, commonly present in the surrounding environment of the site at this time (Ilkhani 2012), were also identified.

No evidence of the initial stages of animal or plant domestication were observed in the Mesolithic occupations of this region; however, data for the Neolithic shows that communities were producing fully domesticated resources (Table 1).

\section{The Southern Alborz Mountains and the Northern Edge of the Iranian Central Desert}

Tepe Sang-e Chakhmaq is the earliest Neolithic settlement located in the northern ICP (Fig. 9) and is approximately dated to 7100-6800 cal BC (Nakamura 2014; Roustaei et al. 2015). The chronological gap between the Early Neolithic of the northern ICP and the Zagros shows that the Epipaleolithic/Mesolithic lasted longer 


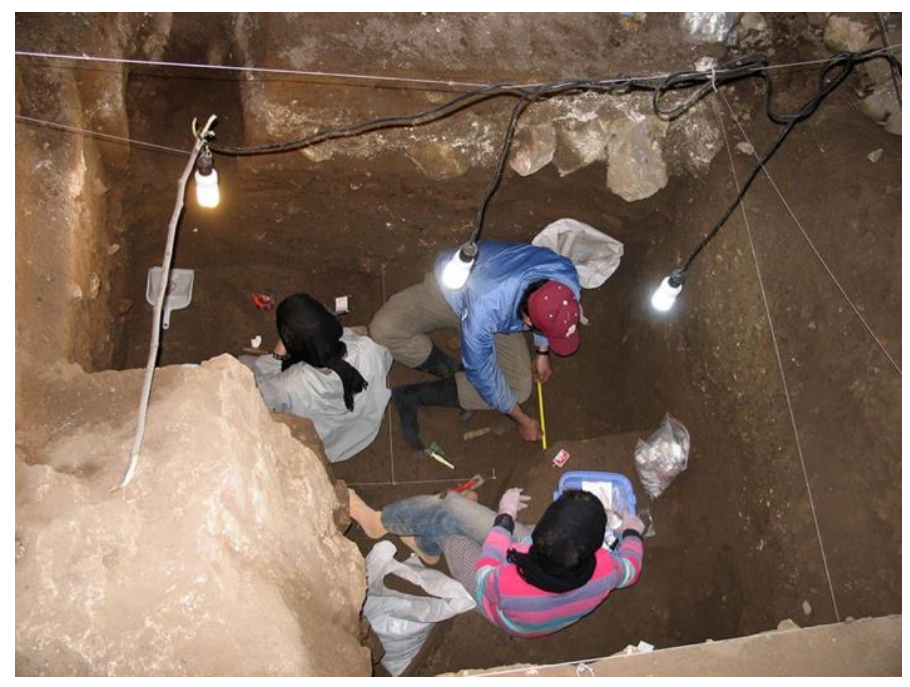

Fig. 8 Komishan cave during the excavation (personal archive of H. Vahdati Nasab) in the ICP, and

that the first Neolithic took 2000 years to reach the area (Roustaei et al. 2015).

Tepe Sang-e Chakhmaq is especially important due to its relatively continuous occupation sequence from the late eighth to the early fifth millennium BC. Two distinct fieldwork seasons were conducted at the site in 1974 (Masuda 1974; Nakamura 2014; Roustaei et al. 2015). According to the first excavations, the western Sang-e Chakhmaq included five architectural layers, of which layers 2 to 5 were attributed to the PPN. The architectural layers included well-constructed square houses of hard-packed earth or lime-coated materials (Masuda 1974). Lithic industries included blades, drills, and cores. Pestles and mortars were also abundant in these layers, revealing the diversity of domestic activities attributed to the Neolithic lifestyle (Thornton 2010). Human and animal clay figurines, and graves (below the house floors) were among other characteristics of the PPN layers in western Sang-e Chankhmaq (Masuda 1974; Roustaei et al. 2015; Thornton 2010). Minor inconsistencies due to the time gap between the two fieldwork seasons should be noted. A ${ }^{14} \mathrm{C}$ sample from PPN remains collected in the 1970 s in the west mound of Sang-e Chakhmaq, recently published, dates to 7940-7610 cal. BC (Masuda et al. 2013, p. 239); however, absolute dating from the excavation conducted in 2009 dates the same remains to 7100-6800 BC (Roustaei et al. 2015). Sang-e Chakhmaq, in the south of the Alborz Mountains, is the only known Neolithic site with reliable evidence of carpological and faunal remains. Fuller et al. (2014b) investigated seed remains from the 1973-1975 excavations but did not find evidence of any indigenous domestication. Tengberg investigated the carpological remains collected from the 2009 excavation and showed that domesticated wheat and barley were present in the earliest levels of the west mound (Roustaei et al. 2015, p. 577). The presence of fully domesticated crops, without any evidence of previous attempts at local 


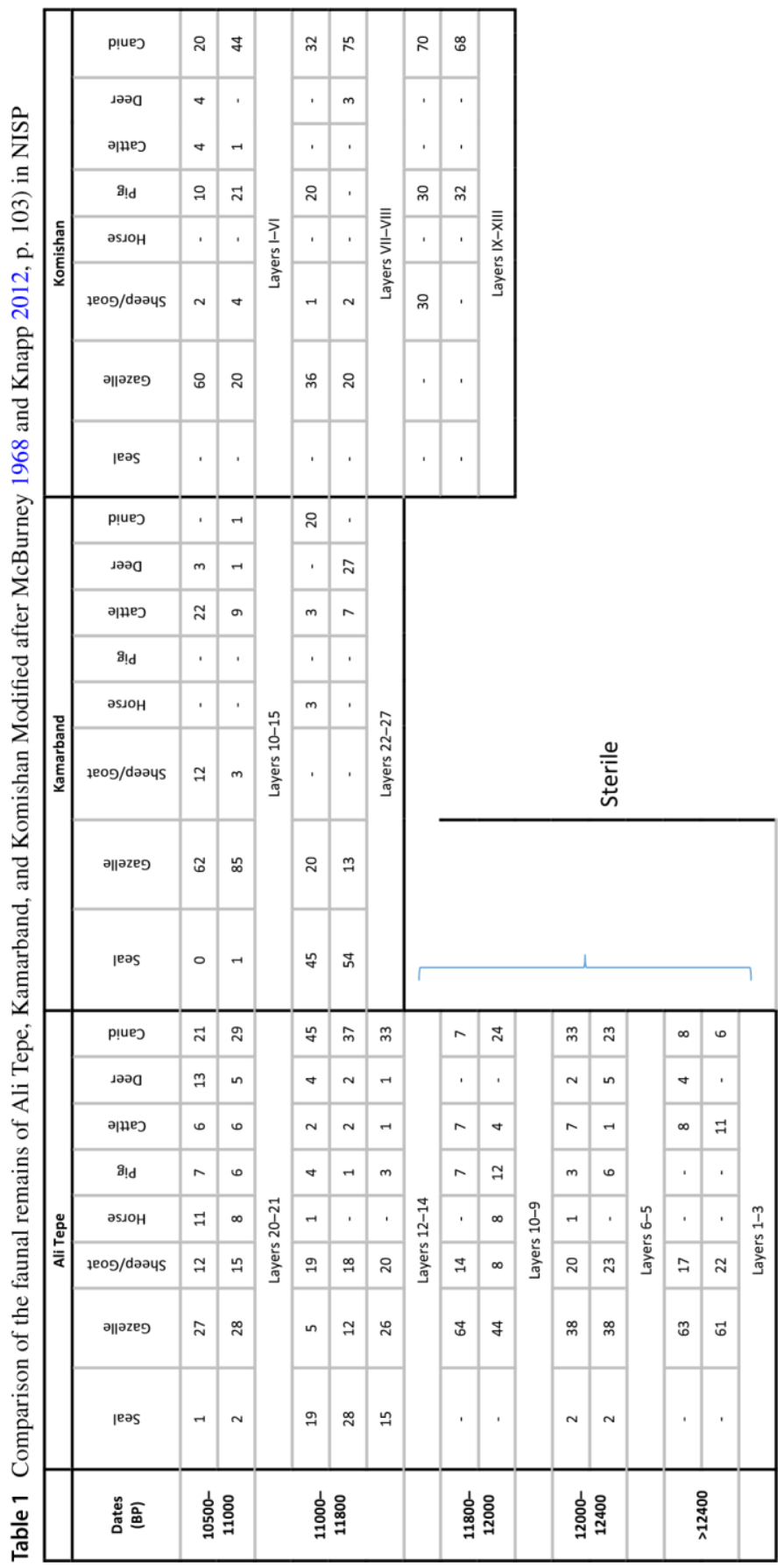




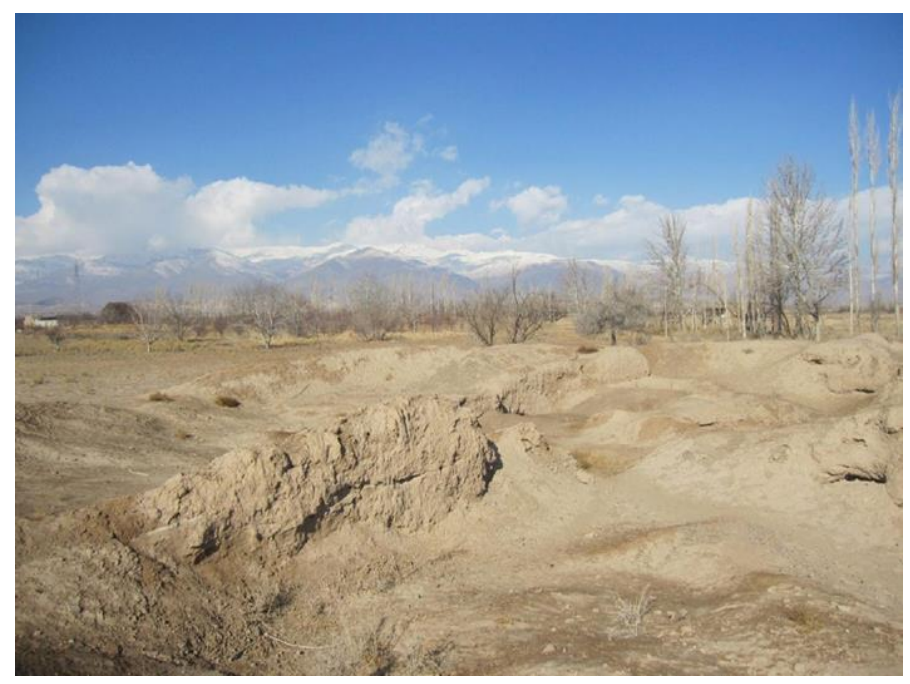

Fig. 9 Sange Chakhmaq west mound, after Tsuneki (2014)

domestication, led the authors to propose an exogenous origin for these domesticated crops. The same applies to faunal remains in the region. According to Roustaei et al. (2015), 'horn cores, the most diagnostic element for distinguishing wild and domestic forms, suggest the presence of already domesticated forms of goat on the West Mound'.

\section{Discussion}

Archaeological evidence from the Near East clearly shows that the initial cultivation stretches back to the Epipaleolithic hunter-gatherer communities (Fuller et al. 2014a; Maher et al. 2012). Pioneering botanical studies have suggested that plants not only played a key role in past human communities but were more important than animals, supplying over 90\% of the human diet (Harlan 1995; cited in Zeder 2012).

Even scant archaeological evidence from the northern Central Desert indicates that the region was never unoccupied (Vahdati Nasab et al. 2013; Vahdati Nasab and Clark 2014; Vahdati Nasab and Hashemi 2016). Perhaps the lack of plant resources in the ICP environment (Clauer et al. 2000; Harris 2010, p. 21; Ollivier et al. 2015) at the onset of the Early Holocene prevented local agricultural innovations. Moreover, limited water resources in the ICP and bounded landscapes surrounded by mountains and desert, especially in the northern flank of the ICP, left only a few kilometres of territory suitable for agriculture. To date, no evidence of plant or fauna domestication, cultivation or management has been identified in the local Mesolithic occupations (Vahdati Nasab et al. 2011; Ilkhani 2012; Knapp 2012). Genetic and archaeological evidence shows that plant and mammal domestication in the Fertile Crescent was not limited to one core area (Fuller et al. 2014a). Only a few species 


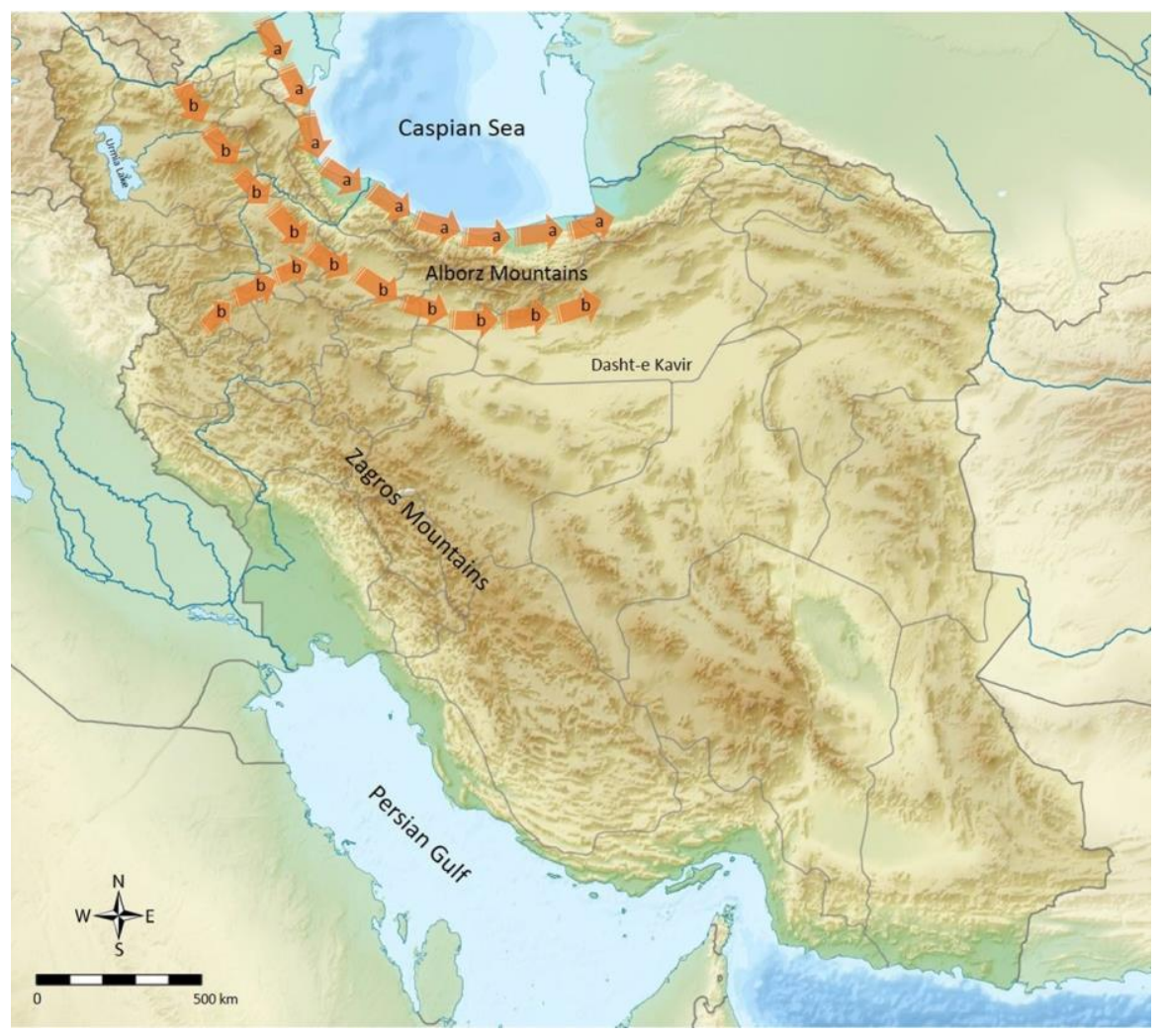

Fig. 10 Migratory pathways through the north of ICP

spread across the neighbouring areas and were turned into major food sources. Domestic wheat in the ICP was introduced from the Zagros, Levant, and perhaps southeastern Turkey (Civán̆ et al. 2013; Mzid et al. 2016). Genetic studies show that barley originated from the eastern part of the Fertile Crescent (Morrell and Clegg 2007), but it is still unclear to what extent the eastern domesticated barley affected the ICP economy. Genetic data also shows that modern domestic goats are native to the southern Taurus and northwestern Zagros Mountains (Naderi et al. 2007, 2008).

The relative proximity of the ICP to the Taurus, southeastern Turkey, and Zagros Mountains may have enhanced trade and contact between the neighbouring communities, thus facilitating access to domesticated resources for the ICP communities. The availability of exogenous domesticated resources might have locally inhibited the domestication of the ancestral wild species whilst triggering the local domestication of other indigenous species (Diamond 1999, p. 99).

Cultural diffusions or population movements may have followed two major pathways to introduce the first domesticated plants and animals to the ICP. The northern pathway extends from southeastern Turkey toward the southeastern Caspian Sea, the Alborz Mountains and southern regions (Fig. 10). The downstream pathway goes 


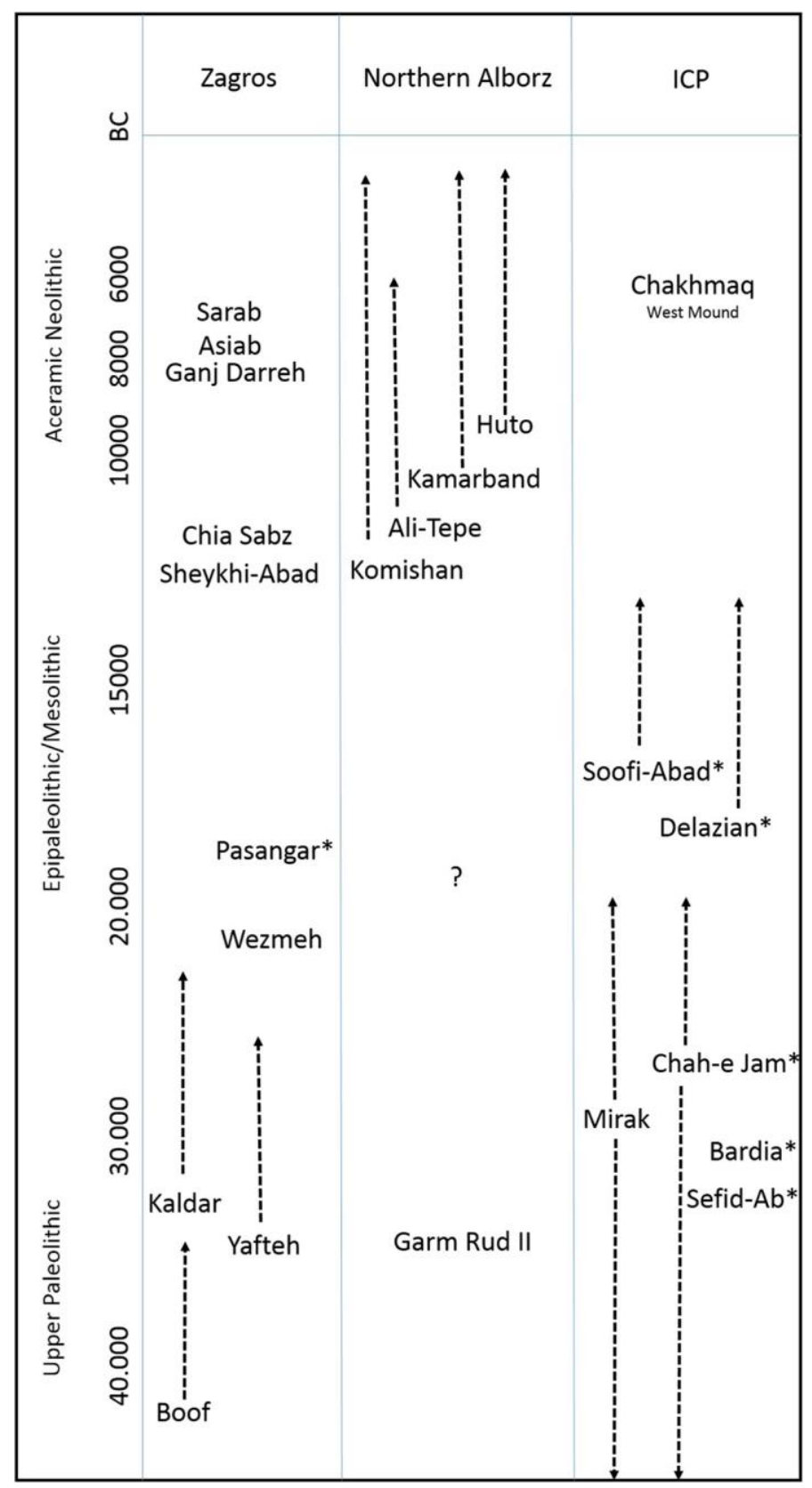

Fig. 11 Chronological diagram showing the end of the Pleistocene/Early Holocene in the Zagros, northern Alborz and ICP

through the Zagros and Taurus fringes towards the northern edge of the Central Desert, across the Zanjan and Qazvin plains (Fig. 10). The northern pathway presents the advantage of being free from any major geomorphological barriers (mountains, seas and deserts) between the Taurus/Zagros Mountains and the southeastern Caspian Sea. The Mediterranean climate of northern Iran was favourable to a Neolithic 
economy relying on dry farming and caprine pastoralism (Harris 2010, pp. 230-232). In addition, the presence of Early Holocene settlements from the western to the eastern flank of the Caspian Sea may have facilitated the long-distance diffusion of goods, ideas and knowledge related to farming technologies.

The diffusion of food production in Iran was gradual and reached the different regions over several thousand years (Fig. 11). Domestication occurred sooner in Zagros than in the upstream and northern Alborz due to its geographic proximity with the core area (e.g. the cultivation of barley and wheat started around 9800 cal BP: Riehl et al. 2013; and goat herding is attested as early as 10,000 cal BP: Zeder 2008). The cultural bonds between the western edge of the ICP and the Zagros Mountains and the climatic similarities between the two regions favoured the diffusion of domesticated plants and mammal species up to the northern flank of the ICP.

Demic versus cultural diffusion between the autochthonous Epipaleolithic foragers in the southeastern Caspian Sea/northeastern ICP and the western Neolithic farmers is still debated. In other regions, like Europe, the picture is complex and it is now demonstrated that contact zones existed between foragers and farmers (Otte and Noiret 2001); communities established wide exchange networks (Rigaud et al. 2015, 2018); the diffusion of farming technologies was irregular and slowed down, stopped and accelerated several times (Bocquet-Appel et al. 2009); and local processes of genetic admixture with varied sources and proportions of hunter-gatherer ancestry occurred in the different regions of Europe (Lipson et al. 2017). Similar processes may have acted in the various parts of the ICP. Two reliable aDNA studies have provided an insight into the population dynamics that occurred during the transition to farming in Iran (Broushaki et al. 2016; Lazaridis et al. 2016, Fig. 2b). In their effort to reconstruct the origin of farming in the ancient Near East, the authors used three aDNA samples from Iran: a Mesolithic one from the Huto cave and two Neolithic ones from the Ganj Darreh Neolithic site, located approximately $1000 \mathrm{~km}$ apart in Zagros. The three samples clustered closely together, suggesting population movements from the Zagros Mountains to the southeastern coast of the Caspian Sea.

\section{Conclusion}

The recurrent stratigraphic gap between the Mesolithic and the Neolithic occupations of the region challenges the local origin of the farming economy. In contrast to the southwestern Asia PPN (Matthews et al. 2010; Peters et al. 1999; Zeder and Hesse 2000; Riehl et al. 2013), the lack of evidence of wild fauna and plant resource management preceding the exploitation of fully domesticated species in the ICP challenges the local origin hypothesis. Chronological, biogeographical and genetic data indicate that the domesticated goats, sheep, and crops identified in the southeastern Caspian Sea area, northeastern Iran and southwestern Turkmenistan originated in the Fertile Crescent (Fuller et al. 2012; Zeder 2011).

The geographic position of the ICP between the Zagros and western Central Asia implies that the region probably played a key role in the eastward diffusion of farming technologies. Data available for western Central Asia mostly relies on Chakhmaq, 
where a strong correspondence with the PPN from Zagros has been observed (rectangular single-room architecture with lime-coated floors and internal fireplaces, clay figures, small stone axes, stone industries, and imported obsidian: Roustaei et al. 2015). The apparently rapid movement of farmers to northeastern Iran and Central Asia was facilitated by an east-west oriented 'corridor' across northern Iran, running from the northern Zagros (south of the Caspian Sea) to as far east as modern-day Mashhad in northeastern Iran (Harris et al. 1998, 2010, pp. 230-232). Regarding recent data on the emergence of farming in the ICP, the relatively sudden appearance of the farming economy in this area suggests that the region was a hot spot of connections and population movements favourable to the diffusion of farming technologies in other surrounding areas, including western Central Asia (Fig. 11).

We still know very little about the role of the autochthonous foragers in the spread of agriculture in the ICP. Evidence of Epipaleolithic/Mesolithic and Late Neolithic occupations in the southeastern Caspian Sea area and northeastern ICP indicate that the region was never unoccupied, despite the absence of evidence of a transitional economy in the multi-layered sites of the region. Many interactions (competition and conflict, transfer of materials and ideas, intermarriage, etc.) might have taken place between incoming farming groups and indigenous foragers. The Neolithisation of the southeastern Caspian Sea and northern ICP was not a linear phenomenon, but likely resulted from multiple population movements and the circulation of cultural traits between communities.

Acknowledgements We would like to thank the anonymous reviewers of the Journal of World Prehistory for their constructive and useful comments. We also like to thank Sarah Wright for her productive help. This work was supported by the French National Research Agency under the IDEX Bordeaux NETAWA Emergence Project No. ANR-10-IDEX-03-02 'Out of the Core: Exploring social NETworks at the dawn of Agriculture in Western Asia 10000 years ago’.

\section{References}

Ammerman, A. J., \& Biagi, P. (2003). The widening harvest. The Neolithic transition in Europe: Looking back, looking forward. Boston: Archaeological Institute of America.

Azizi, G., Akbari, T., Hashemi, H., Yamani, M., Maghsoudi, M., \& Abasi, A. (2013). Pollen analysis for reconstruction the palaeoclimatic phases in Lake Neor during the late-Pleistocene to Holocene. Physical Geography Research Quarterly, 45(1), 1-20.

Barker, G. (2009). The agricultural revolution in prehistory: Why did foragers become farmers? Oxford: Oxford University Press.

Bar-Yosef, O., \& Belfer-Cohen, A. (1989). The origins of sedentarism and farming communities in the Levant. Journal of World Prehistory, 3(4), 447-498.

Bar-Yosef, O., \& Valla, F. (1990). The Natufian culture and the origin of the Neolithic in the Levant. Current Anthropology, 31(4), 433-436.

Binford, L. R. (1968). Post-Pleistocene adaptations. In S. R. Binford \& L. R. Binford (Eds.), New perspectives in archaeology (pp. 313-341). Chicago: Aldine.

Birks, H. H., Gelorini, V., Robinson, E., \& Hoek, W. Z. (2015). Impacts of Paleoclimate change 600008000 years ago on humans and their environments in Europe: Integrating palaeoenvironmental and archaeological data. Quaternary International, 378, 4-13.

Bocquet-Appel, J.-P. (2002). Paleoanthropological traces of a Neolithic demographic transition. Current Anthropology, 43, 637-650. 
Bocquet-Appel, J.-P. (2008). The Neolithic demographic transition, population, pressure and cultural change. Comparative Civilizations Review, 58, 36-49.

Bocquet-Appel, J.-P., Naji, S., Linden, M. V., \& Kozlowski, J. K. (2009). Detection of diffusion and contact zones of early farming in Europe from the space-time distribution of $14 \mathrm{C}$ dates. Journal of Archaeological Science, 36, 807-820.

Bordes, J. G., \& Shidrang, S. (2009). La séquence Baradostienne de Yafteh (Khorramabad, Lorestan, Iran). In M. Otte, F. Biglari, \& J. Jaubert (Eds.), Iran Palaeolithic/Le paléolithique d'Iran: Proceedings of the XV world congress UISPP 28 (Lisbon, 4-9 September 2006), session C15. British Archaeological Reports International Series 1968 (pp. 85-100). Oxford: Archaeopress.

Bowles, S. (2011). Cultivation of cereals by the first farmers was not more productive than foraging. Proceedings of the National Academy of Sciences, 108(12), 4760-4765.

Broushaki, F., Thomas, M. G., Link, V., López, S., van Dorp, L., Kirsanow, K., et al. (2016). Early Neolithic genomes from the eastern Fertile Crescent. https ://doi.org/10.1126/scien ce.aaf79 43.

Brown, T. A., Jones, M. K., Powell, W., \& Allaby, R. G. (2009). The complex origins of domesticated crops in the Fertile Crescent. Trends in Ecology \& Evolution, 24(2), 103-109.

Brown, K. S., Marean, C. W., Jacobs, Z., Schoville, B. J., Oestmo, S., Fisher, E. C., et al. (2012). An early and enduring advanced technology originating 71,000 years ago in South Africa. Nature, 491(7425), 590-593.

Civáň, P., Ivaničová, Z., \& Brown, T. A. (2013). Reticulated origin of domesticated emmer wheat supports a dynamic model for the emergence of agriculture in the Fertile Crescent. PLOS ONE, 8(11), e81955.

Clauer, N., Chaudhuri, S., Toulkeridis, T., \& Blanc, G. (2000). Fluctuations of Caspian Sea level: Beyond climatic variations? Geology, 28(11), 1015-1018.

Conard, Nicholas, \& Ghasidian, E. (2011). The Rostamian culture group and the taxonomy of the Iranian upper Paleolithic. In N. J. Conard, P. Drechsler, \& A. Morales (Eds.), Between sand and sea: The archaeology and human ecology of southwestern Asia. Festschrift in honor of Hans-Peter Uerpmann. Tübinger Monographien zur Urgeschichte (pp. 33-52). Tübingen: Kerns Verlag.

Conard, N. J., Ghasidian, E. \& Heydari Guran, S. (2009).The open-air late paleolithic site of Bardia and the paleolithic occupation of the Qaleh Gusheh sand dunes, Esfahan Province, Iran. In M. Otte, F. Biglari, \& J. Jaubert (Eds.), Iran Palaeolithic/Le paléolithique d'Iran: Proceedings of the XV world congress UISPP 28 (Lisbon, 4-9 September 2006), session C15. British Archaeological Reports International Series 1968 (pp. 141-154). Oxford: Archaeopress.

Conard, N. J., Ghasidian, E., Heydari, S., Naderi, R., \& Zeidee, M. (2007). The 2006 season of the Tübingen Iranian Stone Age Research Project in the provinces of Fars and Markazi. In Fazeli, H. (Ed.), Archaeological reports 7.2. On the occasion of the 9th Annual Symposium on Iranian Archaeology (pp. 43-67). Tehran: ICAR.

Coolidge, J. (2005). Southern Turkmenistan in the Neolithic: A petrographic case study. Oxford: Archaeopress.

Coon, C. S. (1951). Cave explorations in Iran, 1949. Philadelphia: University of Pennsylvania Museum.

Coon, C. S. (1952). Excavations in Hotu cave, Iran, 1951: A preliminary report. Proceedings of the American Philosophical Society, 96(3), 231-249.

Davis, R. S. (1990). Central Asian hunter-gatherers at the Last Glacial Maximum. In O. Soffer \& C. Gamble (Eds.), The world at 18000 BP. Vol. 1: High latitudes (pp. 266-275). London: Unwin Hyman.

Davis, R. S., \& Ranov, V. A. (1999). Recent work on the Paleolithic of Central Asia. Evolutionary Anthropology Issues News and Reviews, 8(5), 186-193.

Derevianko, A. P. (2010). Three scenarios of the Middle to Upper Paleolithic transition. Archaeology, Ethnology and Anthropology of Eurasia, 38(4), 2-38.

Diamond, J. (1999). Guns, germs and steel: The fates of human societies. New York: Norton.

Djamali, M., de Beaulieu, J. L., Shah-Hosseini, M., Andrieu-Ponel, V., Ponel, P., Amini, A., et al. (2008). A Late Pleistocene long pollen record from Lake Urmia, NW Iran. Quaternary Research, 69(3), 413420.

Fisher, W. B. (1968). Physical geography. In W. B. Fisher (Ed.), The Cambridge history of Iran. Volume 1: The land of Iran (pp. 1-110). Cambridge: Cambridge University Press.

Flannery, K. (1969). Origins and ecological effects of early domestication in Iran and the Near East. In P. Ucko \& G. Dimbleby (Eds.), The domestication of plants and animals (pp. 73-100). London: Aldine. 
Fuller, D. Q., Denham, T., Arroyo-Kalin, M., Lucas, L., Stevens, C. J., Qin, L., et al. (2014a). Convergent evolution and parallelism in plant domestication revealed by an expanding archaeological record. Proceedings of the National Academy of Sciences, 111(17), 6147-6152.

Fuller, D. Q., Lucas, L., \& Stevens, C. (2014b). Charred remains from Tappeh Sang-e Chakhmaq, and a consideration of early wheat diversity on the eastern margins of the Fertile Crescent. In The first farming village in northeast Iran and Turan: Tappeh Sang-e Chakhmaq and beyond, February 10 11, 2014 (program and abstracts). Tsukuba: University of Tsukuba.

Fuller, D. Q., Willcox, G., \& Allaby, R. G. (2012). Early agricultural pathways: Moving outside the 'core area' hypothesis in Southwest Asia. Journal of Experimental Botany, 63(2), 617-633.

Gregg, M. W., \& Thornton, C. P. (2012). A preliminary analysis of prehistoric pottery from Carleton Coon's excavations of Hotu and Belt Caves in northern Iran: Implications for future research into the emergence of village life in western Central Asia. International Journal of Humanities, 19(3), $56-94$.

Groucutt, H. S., Petraglia, M. D., Bailey, G., Scerri, E. M., Parton, A., Clark-Balzan, L., et al. (2015). Rethinking the dispersal of Homo sapiens out of Africa. Evolutionary Anthropology: Issues, News, and Reviews, 24(4), 149-164.

Harlan, J. R. (1995). The living fields: Our agricultural heritage. Cambridge: Cambridge University Press.

Harris, D. (2010). Environmental changes in the Pleistocene and Holocene. In D. Harris (Ed.), Origins of agriculture in western Central Asia: An environmental-archaeological study (pp. 19-26). Philadelphia: University of Pennsylvania Museum of Archaeology and Anthropology.

Harris, D. R., Damania, A. B., Valkoun, J., Willcox, G., \& Qualset, C. O. (1998). The spread of Neolithic agriculture from the Levant to western Central Asia. In A. B. Damania, J. Valkoun, G. Willcox, \& C. O. Qualset (Eds.), The origins of agriculture and crop domestication: Proceedings of the Harlan symposium, 10-14 May 1997, Aleppo, Syria (pp. 65-82). Aleppo: International Center for Agricultural Research in the Dry Areas.

Heydari Guran, S., \& Ghasidian, E. (2011). Palaeolithic survey in the Arisman region, western Central Iranian Plateau. In A. Vatandoust, H. Parzinger \& B. Helwing (Eds.), Early mining and metallurgy on the western Central Iranian Plateau: Report on the first five years of research of the Joint IranianGerman Research Project. Archäologie in Iran und Turan 9 (pp. 484-493). Mainz am Rhein: Philipp von Zabern.

Ilkani, H. (2012). Preliminary report of Komishan archaeobotanical studies. Unpublished report.

Jayez, M., \& Vahdati Nasab, H. (2016). A separation: Caspian Mesolithic vs Trialetian lithic industry: A research on the excavated site of Komishan, southeast of the Caspian Sea, Iran. Paléorient, 42(1), 75-94.

Karimi, A., Frechen, M., Khademi, H., Kehl, M., \& Jalalian, A. (2011). Chronostratigraphy of loess deposits in northeast Iran. Quaternary International, 234(1-2), 124-132.

Kehl, M. (2009). Quaternary climate change in Iran: The state of knowledge. Erdkunde, 63(1), 1-17.

Knapp, Z. E. (2012). A zooarchaeological study of the Epi-Palaeolithic faunal assemblage from Komishan Cave, Mazandaran, Iran. Unpublished dissertation presented for MSc in Bioarchaeology. Department of Archaeology, University of Nottingham, UK.

Krinsley, D. B., \& Air Force Cambridge Research Laboratories, Geological Survey. (1970). A geomorphological and paleoclimatological study of the playas of Iran. Bedford, MA/Washington, DC: U.S. Air Force, Cambridge Research Laboratories/Geological Survey.

Lazaridis, I., Nadel, D., Rollefson, G., Merrett, D. C., Rohland, N., Mallick, S., et al. (2016). Genomic insights into the origin of farming in the ancient Near East. Nature, 536(7617), 419.

Lipson, M., Szécsényi-Nagy, A., Mallick, S., Pósa, A., Stégmár, B., Keerl, V., et al. (2017). Parallel palaeogenomic transects reveal complex genetic history of early European farmers. Nature, 551, 368.

Maher, L. A., Richter, T., \& Stock, J. T. (2012). The Pre-Natufian Epipaleolithic: Long-term behavioral trends in the Levant. Evolutionary Anthropology: Issues, News, and Reviews, 21(2), 69-81.

Mamedov, A. V. (1997). The Late Pleistocene-Holocene history of the Caspian Sea. Quaternary International, 41(42), 161-166.

Marshall, J. L. (2012). Missing links: Demic diffusion and the development of agriculture on the Central Iranian Plateau. Durham University e-Theses: http://ethes es.dur.ac.uk/3547/. Accessed 2015.

Mashkour, M. (2004). A preliminary study of faunal remains from Komishan Cave in Mazandaran. Gozareshhai-i Bastanshenasi, 2, 16.

Mashkour, M., Chahoud, J., \& Mahforouzi, A. (2010). Faunal remains from the Epipaleolithic site of Komishan Cave and its dating: Preliminary results. Iranian Archaeology, 1, 32-37. 
Masuda, S. (1974). Excavations at Tappeh Sang-e Caxmaq. In Proceedings of the 2nd Annual Symposium on Archaeological Research in Iran (pp. 23-33). Tehran: Iranian Center for Archaeological Research.

Masuda, S., Ikeda, A. T., Minami, M., \& Tsuneki, A. (2013). Tappeh Sange Chakhmaq: Investigation of a Neolithic site in the northeastern Iran. In H. Fazeli Nashi (Ed.), The Neolithisation of Iran (p. 201). Oxford: Oxbow.

Matthews, R., Mohammadifar, Y., Matthews, W., \& Motarjem, A. (2010). Investigating the Early Neolithic of western Iran: The Central Zagros Archaeological Project (CZAP). Antiquity, 84(323), $1-3$.

McBurney, C. B. (1968). The cave of Ali Tappeh and the Epi-Palaeolithic in N.E. Iran. Proceedings of the Prehistoric Society, 12, 385-413.

Mellaart, J. (1975). The Neolithic of the Near East. New York: Charles Scribner's Sons.

Morrell, P. L., \& Clegg, M. T. (2007). Genetic evidence for a second domestication of barley (Hordeum vulgare) east of the Fertile Crescent. Proceedings of the National Academy of Sciences, 104(9), 32893294.

Mzid, R., Chibani, F., Ayed, R. B., Hanana, M., Breidi, J., Kabalan, R., et al. (2016). Genetic diversity in barley landraces (Hordeum vulgare L. subsp. vulgare) originated from Crescent Fertile region as detected by seed storage proteins. Journal of Genetics, 95(3), 733-739.

Naderi, S., Rezaei, H. R., Pompanon, F., Blum, M. G., Negrini, R., Naghash, H. R., et al. (2008). The goat domestication process inferred from large-scale mitochondrial DNA analysis of wild and domestic individuals. Proceedings of the National Academy of Sciences, 105(46), 17659-17664.

Naderi, S., Rezaei, H. R., Taberlet, P., Zundel, S., Rafat, S. A., Naghash, H. R., et al. (2007). Largescale mitochondrial DNA analysis of the domestic goat reveals six haplogroups with high diversity. PLoS One, 2(10), e1012.

Nakamura, T. (2014). Radiocarbon dating of charcoal remains excavated from Tappeh Sang-e Chakhmaq. In The first farming village in northeast Iran and Turan: Tappeh Sang-e Chakhmaq and beyond, February 10-11, 2014 (program and abstracts) (pp. 9-12). Tsukuba: University of Tsukuba.

Oberlander, T. M. (1968). The origin of Zagros defiles. In W. B. Fisher (Ed.), The Cambridge history of Iran. Volume 1: The land of Iran (pp. 195-211). Cambridge: Cambridge University Press.

Ollivier, V., Fontugne, M., \& Lyonnet, B. (2015). Geomorphic response and 14C chronology of baselevel changes induced by Late Quaternary Caspian Sea mobility (middle Kura Valley, Azerbaijan). Geomorphology, 230, 109-124. https ://doi.org/10.1016/j.geomo rph.2014.11.010.

Olszewski, D. I. (2013). The Zarzian in the context of the Epipaleolithic Middle East. The International Journal of Humanities, 19(3), 1-20.

Olszewski, D. I., \& Dibble, H. L. (1994). The Zagros Aurignacian. Current Anthropology, 35(1), 68-75.

Otte, M., Biglari, F., Flas, D., Shidrang, S., Zwyns, N., Mashkour, M., et al. (2007). The Aurignacian in the Zagros region: New research at Yafteh cave, Lorestan, Iran. Antiquity, 81(311), 82-96.

Otte, M., \& Noiret, P. (2001). Le Mésolithique du Bassin Pannonien et la formation du Rubané. L'Anthropologie, 105, 409-419.

Peters, J., von den Driesch, A., Helmer, D. \& Sañá Seguí, M. (1999). Early animal husbandry in the Northern Levant. Paléorient, 25(2), 27-48.

Riehl, S., Benz, M., Conard, N. J., Darabi, H., Deckers, K., Nashli, H. F., et al. (2012). Plant use in three pre-pottery Neolithic sites of the northern and eastern Fertile Crescent: A preliminary report. Vegetation History and Archaeobotany, 21(2), 95-106.

Riehl, S., Zeidi, M., \& Conard, N. J. (2013). Emergence of agriculture in the foothills of the Zagros Mountains of Iran. Science, 341(6141), 65-67.

Rigaud, S., d'Errico, F., \& Vanhaeren, M. (2015). Ornaments reveal resistance of north European cultures to the spread of farming. PLoS ONE, 10, e0121166. https ://doi.org/10.1371/journ al.pone.01211 66.

Rigaud, S., Manen, C., \& García-Martínez de Lagrán, I. (2018). Symbols in motion: Flexible cultural boundaries and the fast spread of the Neolithic in the western Mediterranean. PLOS ONE, 13, e0196488. https ://doi.org/10.1371/journ al.pone.01964 88.

Rindos, D. (1984). The origins of agriculture: An evolutionary perspective. Cambridge, MA: Academic Press.

Rose, J. (2010). New light on human prehistory in the Arabo-Persian Gulf Oasis. Current Anthropology, $51(6), 849-883$.

Roustaei, K. (2012). Archaeological survey of the Šahroud area, northeast Iran: A landscape approach. Archäologische Mitteilungen aus Iran und Turan, 44, 191-219.

Roustaei, K. (2016). An emerging picture of the Neolithic of northeast Iran. Iranica Antiqua, 51, 21-56. 
Roustaei, K., Mashkour, M., \& Tengberg, M. (2015). Tappeh Sang-e Chakhmaq and the beginning of the Neolithic in north-east Iran. Antiquity, 89(345), 573-595.

Rowley-Conwy, P., \& Layton, R. (2011). Foraging and farming as niche construction: Stable and unstable adaptations. Philosophical Transactions of the Royal Society B: Biological Sciences, 366, 849-862.

Shea, J. J. (2013). Stone tools in the Paleolithic and Neolithic Near East. New York: Cambridge University Press.

Shidrang, S. (2009). A typo-technological study of an Upper Paleolithic collection from Sefid-Ab, central Iran. In M. Otte, F. Biglari, \& J. Jaubert (Eds.), Iran Palaeolithic/Le paléolithique d'Iran. Proceedings of the XV World Congress UISPP 28 (Lisbon, 4-9 September 2006), session C15.

British Archaeological Reports International Series 1968 (pp. 47-56). Oxford: Archaeopress.

Stevens, L. R., Djamali, M., Andrieu-Ponel, V., \& de Beaulieu, J. L. (2012). Hydroclimatic variations over the last two glacial/interglacial cycles at Lake Urmia, Iran. Journal of Paleolimnology, 47(4), 645660.

Stiner, M. (2001). Thirty years on the 'Broad Spectrum Revolution' and Paleolithic demography. Proceedings of the National Academy of Sciences, 98(13), 6993-6996.

Thornton, C. (2010). Sang-e Chakhmaq. Encyclopedia Iranica. http://www.irani caonl ine.org. Accessed 2013.

Vahdati Nasab, H., Berillon, G., Jamet, G., Hashemi, M., Jayez, M., Khaksar, S., et al. (2019). The openair Paleolithic site of Mirak, northern edge of the Iranian Central Desert (Semnan, Iran): Evidence of repeated human occupations during the late Pleistocene. Comptes Rendus Palevol, 18(4), 465-478.

Vahdati Nasab, H., \& Clark, G. A. (2014). The upper paleolithic of the Iranian central desert: The Delazian sites, Semnan Province-A case study. Archäologische Mitteilungen aus Iran und Turan (AMIT), 46, $1-21$.

Vahdati Nasab, H., Clark, G. A., \& Torkamandi, S. (2013). Late Pleistocene dispersal corridors across the Iranian Plateau: A case study from Mirak, a Middle Paleolithic site on the northern edge of the Iranian Central Desert (Dasht-e Kavir). Quaternary International, 300, 267-281.

Vahdati Nasab, H., \& Hashemi, M. (2016). Playas and Middle Paleolithic settlement of the Iranian Central Desert: The discovery of the Chah-e Jam Middle Paleolithic site. Quaternary International, 408, 140152.

Vahdati Nasab, H., Jayez, M., Nobari, A. H., Nadooshan, F. K., Ilkhani, H., \& Mahfroozi, A. (2011). Komishan Cave, Mazandaran, Iran: An Epipalaeolithic and later site on the southern Caspian Sea. Antiquity, 85, 328.

Vlaminck, S., Kehl, M., Rolf, C., Franz, S. O., Lauer, T., Lehndorff, E., et al. (2018). Late Pleistocene dust dynamics and pedogenesis in southern Eurasia: Detailed insights from the loess profile Toshan (NE Iran). Quaternary Science Reviews, 180, 75-95.

Weninger, B., Alram-Stern, E., Bauer, E., Clare, L., Danzeglocke, U., Jöris, O., et al. (2006). Climate forcing due to the $8200 \mathrm{cal}$ yr BP event observed at Early Neolithic sites in the eastern Mediterranean. Quaternary Research, 66, 401-420.

Wright, K. I. (2014). Domestication and inequality? Households, corporate groups and food processing tools at Neolithic Çatalhöyük. Journal of Anthropological Archaeology, 33, 1-33. https ://doi. org/10.1016/j.jaa.2013.09.007.

Yanina, T. A. (2012). Correlation of the Late Pleistocene paleogeographical events of the Caspian Sea and Russian Plain. Quaternary International, 271, 120-129.

Zeder, M. A. (2008). Domestication and early agriculture in the Mediterranean Basin: Origins, diffusion, and impact. Proceedings of the National Academy of Sciences, 105(33), 11597-11604.

Zeder, M. (2011). The origins of agriculture in the near east. Current Anthropology, 52(Supplement 4), S221-S235.

Zeder, M. (2012). Pathways to animal domestication. In P. Gepts, T. Famula, R. Bettinger, S. Brush, A. Damania, P. McGuire, et al. (Eds.), Biodiversity in agriculture: Domestication evolution and sustainability (pp. 227-259). Cambridge: Cambridge University Press. https ://doi.org/10.1017/ cbo97 81139019514.013.

Zeder, M. A., \& Hesse, B. (2000). The initial domestication of goats (Capra hircus) in the Zagros Mountains 10,000 years ago. Science, 287(5461), 2254-2257.

Publisher's Note Springer Nature remains neutral with regard to jurisdictional claims in published maps and institutional affiliations. 